\title{
Preventive but Not Late Amiloride Therapy Reduces Morbidity and Mortality of Lung Disease in BENaC-overexpressing Mice
}

\author{
Zhe Zhou ${ }^{1 *}$, Diana Treis ${ }^{1 *}$, Susanne C. Schubert ${ }^{1}$, Maria Harm¹, Jolanthe Schatterny ${ }^{1}$, Stephanie Hirtz ${ }^{1}$, \\ Julia Duerr', Richard C. Boucher ${ }^{2}$, and Marcus A. Mall ${ }^{1}$ \\ ${ }^{1}$ Pediatric Pulmonology and Cystic Fibrosis Center, Department of Pediatrics III, University of Heidelberg, Heidelberg, Germany; and \\ ${ }^{2}$ Cystic Fibrosis/Pulmonary Research and Treatment Center, School of Medicine, The University of North Carolina at Chapel Hill, \\ Chapel Hill, North Carolina
}

\begin{abstract}
Rationale: Increased airway $\mathrm{Na}^{+}$absorption mediated by epithelial $\mathrm{Na}^{+}$channels $(\mathrm{ENaC})$ is a characteristic abnormality in the pathogenesis of cystic fibrosis (CF) lung disease. However, inhalation therapy with the $\mathrm{ENaC}$ blocker amiloride did not have therapeutic benefits in patients with CF with established lung disease.

Objectives: We hypothesized that preventive inhibition of increased $\mathrm{Na}^{+}$absorption in a structurally normal lung may be required for effective therapy of CF lung disease in vivo, and that therapeutic effects of late amiloride intervention may be impeded by the chronic disease process.

Methods: To test this hypothesis in vivo, we used the $\beta E N a C$-overexpression mouse as a model of $\mathrm{CF}$ lung disease and determined therapeutic effects of preventive versus late amiloride therapy on survival, airway mucus plugging, chronic bronchitis, and airway remodeling.

Measurements and Main Results: We show that early intervention, i.e., from the first day of life, with the intranasal administration of amiloride significantly reduced pulmonary mortality, airway mucus obstruction, epithelial necrosis, goblet cell metaplasia, and airway inflammation in $\beta E N a C$-overexpressing mice. In contrast, consistent with previous human trials in patients with $\mathrm{CF}$, amiloride administration did not have benefits if treatment was started after the development of $\mathrm{CF}$-like lung disease in $\mathrm{BENaC}$-overexpressing mice.

Conclusions: We conclude that preventive inhibition of increased airway $\mathrm{Na}^{+}$absorption provides an effective therapy for CF-like lung disease in vivo. These results suggest that amiloride therapy may be an effective preventive therapy for patients with CF if initiated early in life before the onset of lung disease.
\end{abstract}

Keywords: epithelial $\mathrm{Na}^{+}$channels; airway surface liquid; cystic fibrosis; pharmacotherapy; mucus

Cystic fibrosis (CF) lung disease remains one of the most frequent lethal hereditary diseases, and is caused by mutations in the cystic fibrosis transmembrane conductance regulator $(C F T R)$ gene $(1$, 2). CFTR encodes a cAMP-dependent $\mathrm{Cl}^{-}$channel and regulates the epithelial $\mathrm{Na}^{+}$channel (ENaC) (3-7). In CF airway epithelia, CFTR-mediated $\mathrm{Cl}^{-}$secretion is defective and $\mathrm{ENaC}$-mediated

(Received in original form March 21, 2008; accepted in final form October 2, 2008) *These authors contributed equally to this work.

Supported by the Marie Curie Excellence Grant from the European Commission (MEXT-CT-2004-013666), the Cystic Fibrosis Foundation (MALL04G0), and the Deutsche Forschungsgemeinschaft (DFG MA 2081/3-2).

Correspondence and requests for reprints should be addressed to Marcus A. Mall, M.D., Pediatric Pulmonology and Cystic Fibrosis Center, Department of Pediatrics III, University of Heidelberg, Im Neuenheimer Feld 153, 69120 Heidelberg, Germany. E-mail: Marcus.Mall@med.uni-heidelberg.de

This article has an online supplement, which is accessible from this issue's table of contents at www.atsjournals.org

Am J Respir Crit Care Med Vol 178. pp 1245-1256, 2008

Originally Published in Press as DOI: 10.1164/rccm.200803-442OC on October 10, 2008

Internet address: www.atsjournals.org

\section{AT A GLANCE COMMENTARY}

Scientific Knowledge on the Subject

Increased airway $\mathrm{Na}^{+}$absorption produces airway surface dehydration and deficient mucociliary clearance, and plays an important role in the pathogenesis of cystic fibrosis (CF) lung disease.

What This Study Adds to the Field

This study demonstrates that early, but not late, inhibition of increased airway $\mathrm{Na}^{+}$absorption provides an effective therapy for $\mathrm{CF}$-like lung disease in a murine disease model. This preventive paradigm may potentially be of benefit for the treatment of patients with $\mathrm{CF}$.

$\mathrm{Na}^{+}$absorption is increased (8-11). Evidence from in vitro studies demonstrated that these ion transport defects in $\mathrm{CF}$ airways cause airway surface liquid (ASL) volume depletion, defective mucus clearance, and mucus adhesion, suggesting that ASL volume depletion is a key mechanism in the pathogenesis of CF lung disease (12-14). Further, a selective increase of airway $\mathrm{Na}^{+}$ absorption by airway-specific overexpression of the $\beta$-subunit of $\mathrm{ENaC}$ (encoded by the Scnn1b gene) in mice demonstrated that accelerated $\mathrm{Na}^{+}$transport alone is sufficient to produce ASL volume depletion and the subsequent spectrum of CF-like lung disease, including airway mucus obstruction, goblet cell metaplasia, chronic neutrophilic airway inflammation, impaired clearance of bacterial pathogens, and ultimately mortality (15-18). Further, recent studies identified additional abnormalities in the lungs of $\beta E N a C$-overexpressing mice that have been reported less frequently in patients with $\mathrm{CF}$, including airway epithelial necrosis, transient airway eosinophilia, and emphysema (17). Taken together, these results indicated that increased airway $\mathrm{Na}^{+}$absorption plays a critical role in the pathogenesis of $\mathrm{CF}$ and suggest $\mathrm{ENaC}$ as a pharmacologic target to improve airway surface hydration for treatment of a disease-initiating step in CF lung disease.

However, in previous clinical trials, inhalation therapy with the ENaC inhibitor amiloride (19) did not demonstrate significant therapeutic benefits in patients with $\mathrm{CF}$ with established lung disease $(20,21)$. Recent studies of antimicrobial agents in $\mathrm{CF}$ suggest that early intervention may be more effective in reducing bacterial infection than treatment of established infection in $\mathrm{CF}$ lung disease $(22,23)$. Accordingly, we hypothesized that therapeutic effects of aerosolized amiloride were also impeded by factors related to the chronic disease process and that preventive inhibition of increased $\mathrm{Na}^{+}$absorption, started in a structurally normal neonatal CF lung, may be required to effectively treat $\mathrm{CF}$ lung disease. To test this hypothesis in vivo, we used the $\beta \mathrm{ENaC}$ overexpressing mouse as a model of CF lung disease $(15,16)$ and 
compared the effects of preventive amiloride treatment versus amiloride intervention after the onset of lung disease on survival, airway mucus obstruction, epithelial necrosis, airway remodeling, and airway inflammation. Some of the results of this study have been reported previously in the form of abstracts $(24,25)$.

\section{METHODS}

\section{Experimental Animals}

All animal studies were approved by the Regierungspräsidium Karlsruhe, Germany. The generation of $\beta E N a C$-overexpressing mice (line 6608) has been described previously (15). Further details on experimental animals are provided in the online supplement.

\section{Amiloride Treatment Studies}

Amiloride hydrochloride (Sigma-Aldrich, Taufkirchen, Germany) was dissolved in sterile distilled water $\left(\mathrm{ddH}_{2} \mathrm{O}\right)$. Newborn, 5-day-old, and 4 -week-old $\beta \mathrm{ENaC}$-overexpressing mice and wild-type littermates were treated by intranasal instillation of amiloride $(10 \mathrm{mmol} / \mathrm{L} ; 1 \mu \mathrm{l} / \mathrm{g}$ body weight; three times per day) or equal volumes of vehicle $\left(\mathrm{ddH}_{2} \mathrm{O}\right)$ alone for a period of 13 to 14 days. Pulmonary deposition studies in newborn mice indicated that approximately $4 \%$ of the amiloride dose delivered by intranasal instillation was deposited into the lungs (see Figure E1 in the online supplement). During amiloride treatment, growth and survival were monitored, and deficits in body mass observed in amiloride-treated mice were replaced by subcutaneous injections of isotonic saline $(\mathrm{NaCl}$ $0.9 \%)$ as described in the online supplement.

Twelve hours after the last treatment, bronchoalveolar lavage (BAL) was performed; lungs were removed for histology, morphometry, and transcript expression studies; and serum and urine were sampled to determine renal effects of absorbed amiloride on $\mathrm{Na}^{+}$and $\mathrm{K}^{+}$concentrations as described in the online supplement. To determine the effect of amiloride on airway epithelial necrosis, $\beta E N a C$-overexpressing mice and wild-type littermates were treated from the first day of life for a period of 3 days and the lungs were removed for histology 12 hours after the last treatment. To examine if effects of preventive amiloride therapy during the neonatal period were sustained in the absence of continuous $\mathrm{ENaC}$ blockade, amiloride withdrawal studies were performed as described in the online supplement. Finally, to determine if systemic application of amiloride or $\mathrm{NaCl} 0.9 \%$ had effects on lung disease, $\beta E N a C$-overexpressing mice were treated with subcutaneous injections of amiloride or $\mathrm{NaCl} 0.9 \%$ alone as described in the online supplement (Figure E3). Endpoint studies were performed by investigators blinded to the genotype and the treatment of the mice.

\section{BAL Cell Counts and Cytokine Measurements}

BAL was obtained and cell counts were determined as previously described (15). Macrophage size was determined as described in the online supplement. IL-13 concentrations were measured in BAL using ELISA (R\&D Systems, Minneapolis, MN) according to manufacturer's instructions as previously described (17).

\section{Histology and Airway Morphometry}

Lungs were removed through a median sternotomy, fixed, paraffin embedded, sectioned, and stained with hematoxylin and eosin (H\&E) or Alcian blue periodic acid-Schiff (AB-PAS) as previously described (17). Lungs were sectioned transversally at the level of the proximal intrapulmonary main axial airway near the hilus, and at the distal intrapulmonary axial airway as described in the online supplement. Airway mucus obstruction was assessed stereologically by determining mucus volume density as previously described $(17,26-28)$. The volume density of the airway epithelium was determined as a measure of epithelial height. Goblet cells were identified by the presence of intracellular ABPAS-positive material, degenerative airway epithelial cells were identified by morphologic criteria, and numeric cell densities were quantitated by counting epithelial cells per $\mathrm{mm}$ of the basement membrane. Further details on morphometry are provided in the online supplement.

\section{Real-Time RT-PCR}

Quantitative RT-PCR for Muc5ac, Gob5, $\beta E N a C$, and Gapdh was performed on an Applied Biosystems 7500 Real Time PCR System using TaqMan universal PCR master mix and inventoried TaqMan gene expression assays according to the manufacturer's instructions (Applied Biosystems, Darmstadt, Germany). Relative fold changes in target gene expression were calculated from the efficiency of the PCR reaction and the crossing point deviation between samples from the four treatment groups, and determined by normalization to expression of the reference gene Gapdh, as previously described (17).

\section{Statistics}

Data were analyzed with SigmaStat version 3.1 (Systat Software, Erkrath, Germany) and are reported as mean \pm SEM. We performed statistical analyses using Student's $t$ test, Mann-Whitney Rank Sum test, one-way ANOVA, Kruskal-Wallis ANOVA on Ranks, and KaplanMeier survival analysis as appropriate, and $P<0.05$ was accepted to indicate statistical significance.

\section{RESULTS}

\section{Preventive Amiloride Therapy Reduces Mortality of CF-like Lung Disease in $\beta E N a C$-overexpressing Mice}

The lungs of $\beta E N a C$-overexpressing mice are structurally normal at birth, but develop central airway mucus obstruction in the first days of life (15). To evaluate effects of preventive amiloride therapy on CF-like lung disease, amiloride administration to $\beta \mathrm{ENaC}$-overexpressing mice was started on the first day of life (i.e., before the onset of lung disease) using a protocol of intranasal administration of amiloride $(10 \mathrm{mmol} / \mathrm{L} ; 1 \mu \mathrm{l} / \mathrm{g}$ body weight) or vehicle $\left(\mathrm{ddH}_{2} \mathrm{O}\right)$ alone three times daily for a period of 2 weeks. Wild-type littermates were treated with the same protocol to assess for pulmonary toxicity of amiloride therapy. Renal effects of absorbed amiloride were determined by measuring $\mathrm{Na}^{+}$ and $\mathrm{K}^{+}$concentrations in serum and urine, and weight loss due to diuresis. Volume losses were replaced by subcutaneous injections of isotonic saline ( $\mathrm{NaCl} 0.9 \%)$ (Figure E1).

Using this treatment protocol, we first measured the effect of preventive amiloride therapy on survival. Similar to the spontaneous pulmonary mortality observed in previous studies $(15,17)$, vehicle-treated $\beta \mathrm{ENaC}$-overexpressing mice exhibited a mortality rate of approximately 50\% (Figure 1A). Preventive amiloride treatment resulted in a delayed onset, with an overall reduction of pulmonary mortality by approximately $70 \%$ in $\beta E N a C$-overexpressing mice. Amiloride had no adverse effects on survival in wild-type littermates (Figure 1A).

\section{Early Amiloride Therapy Prevents Airway Mucus Obstruction, Goblet Cell Metaplasia, and Mucus Hypersecretion in BENaC-overexpressing Mice}

Our previous studies indicated that mortality in $\beta E N a C$-overexpressing mice is caused by asphyxia due to severe postnatal central airway mucus plugging, and demonstrated that surviving mice develop mucus obstruction, epithelial remodeling with goblet cell metaplasia and epithelial thickening, and mucus hypersecretion in intrapulmonary airways during the first weeks of life $(15,17)$. We, therefore, next measured the effects of preventive amiloride therapy on these characteristic pathologic features in surviving $\beta E N a C$-overexpressing mice. As predicted from previous studies, airway mucus content was significantly elevated in vehicle-treated $\beta \mathrm{ENaC}$-overexpressing mice versus wild-type littermates (Figures 1B and 1C) (17). Preventive amiloride treatment significantly reduced airway mucus obstruction to near-normal values in proximal and distal airway regions of $\beta \mathrm{ENaC}$-overexpressing mice (Figures $1 \mathrm{~B}$ and $1 \mathrm{C}$ ). Further, early amiloride therapy prevented goblet cell metaplasia and epithelial thickening observed in distal airways of vehicle-treated $\beta \mathrm{ENaC}$-overexpressing mice (Figures $1 \mathrm{D}$ and $1 \mathrm{E}$ ). Inhibition of goblet cell metaplasia and airway mucus obstruction was paral- 
A

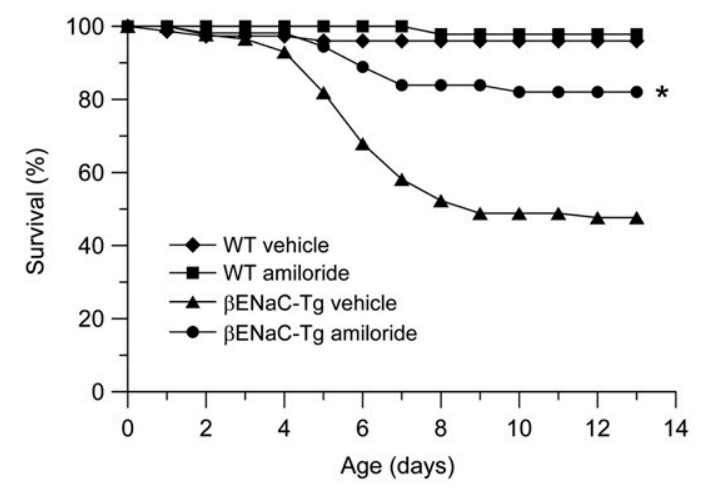

C

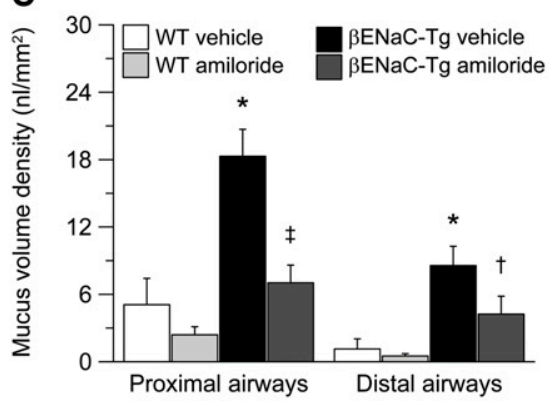

B

$\beta E N a C-T g$

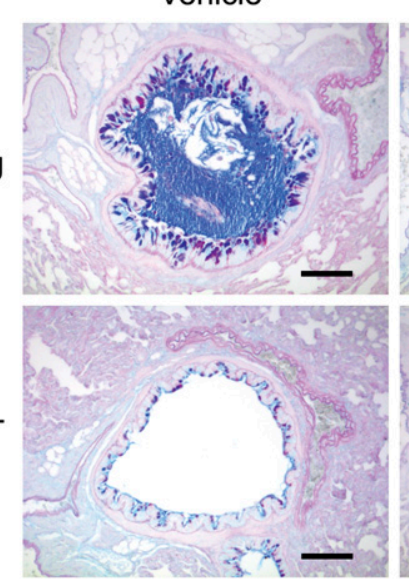

D

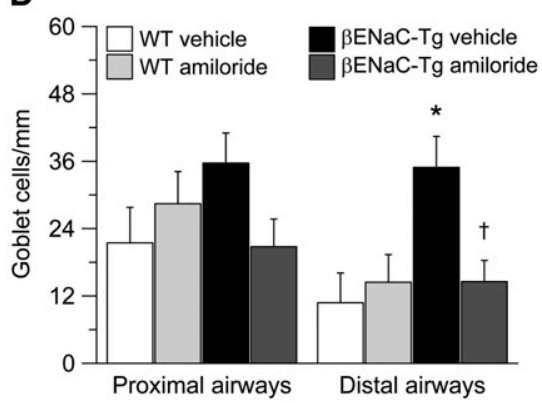

Amiloride

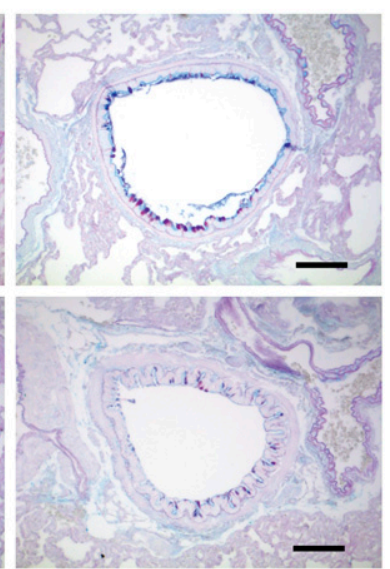

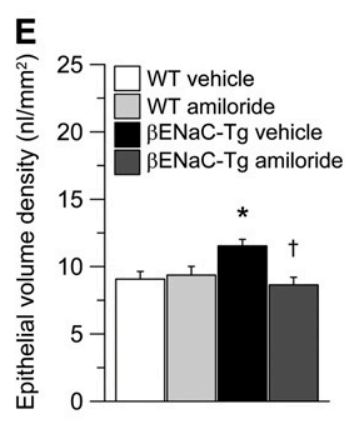

Figure 1. Preventive amiloride therapy reduces mortality, airway mucus obstruction, and epithelial remodeling in $\beta$-subunit of the epithelial $\mathrm{Na}^{+}$ channel $(\beta E N a C)$-overexpressing mice. Effect of preventive amiloride treatment, administered from the first day of life for a period of 2 weeks on $(A)$ survival; $(B$ and $C$ ) airway mucus content, $(D)$ goblet cell counts, and $(E)$ epithelial height in $\beta E N a C$-overexpressing ( $\beta E N a C-T g)$ mice and wild-type (WT) littermates. (A) Survival curves for $\beta E N a C$-overexpressing and wild-type mice treated with amiloride or vehicle alone $(n=46-86$ mice for each group; * $P<0.001$ compared with vehicle-treated $\beta E N a C$-overexpressing mice). (B) Airway histology of $\beta E N a C$-overexpressing and wild-type mice after preventive treatment with amiloride or vehicle. Sections were stained with Alcian blue-periodic acid Schiff (AB-PAS) to determine the presence of intraluminal mucus and goblet cells. Representative of $n=15-27$ mice for each group. Scale bars $=100 \mu \mathrm{m}$. (C) Mucus content was determined by measuring the volume density of AB-PAS-positive material in proximal and distal main axial airways $\left(n=15-27\right.$ mice for each group; ${ }^{*}<0.001$ compared with vehicle-treated wild-type, $\uparrow P<0.05$ compared with vehicle-treated $\beta E N a C$-overexpressing mice, $\neq p<0.001$ compared with vehicletreated $\beta E N a C$-overexpressing mice). ( $D$ ) Goblet cell densities in proximal and distal main axial airways were determined from the number of $A B-$ PAS-positive epithelial cells per $\mathrm{mm}$ of the basement membrane $\left(\mathrm{n}=15-27\right.$ mice for each group; ${ }^{*}<0.01$ compared with vehicle-treated wildtype, $\uparrow P<0.05$ compared with vehicle-treated $\beta E N a C$-overexpressing mice). ( $E$ ) Epithelial height was determined by measuring the volume density of the epithelium in main axial airways $\left(\mathrm{n}=15-27\right.$ mice for each group; ${ }^{*} P<0.001$ compared with vehicle-treated wild-type, ${ }^{\dagger} P<0.01$ compared with vehicle-treated $\beta E N a C$-overexpressing mice).

leled by a significant reduction of transcript levels of the goblet cell marker Gob5 and the airway mucin Muc5ac in lungs from amiloride-treated compared with vehicle-treated $\beta E N a C$-overexpressing mice (Figures $2 \mathrm{~A}$ and $2 \mathrm{~B}$ ). In contrast, preventive $\mathrm{ENaC}$ blocker therapy had no effect on expression of $\beta \mathrm{ENaC}$ mRNA in lungs from $\beta E N a C$-overexpressing mice (Figure $2 \mathrm{C}$ ), indicating that therapeutic effects of amiloride were conferred by pharmacologic inhibition of ENaC-mediated $\mathrm{Na}^{+}$absorption rather than reduced $\beta \mathrm{ENaC}$ expression.

Evaluation of lungs from vehicle- and amiloride-treated wildtype mice did not reveal any signs of pulmonary toxicity caused by amiloride therapy. Specifically, preventive amiloride therapy did not alter airway mucus content, goblet cell numbers, epithelial height, or Gob5 and Muc5ac expression in amiloride-treated compared with vehicle-treated wild-type mice (Figures 1 and 2).

Loss of body mass due to increased diuresis and excretion of $\mathrm{Na}^{+}$in the urine of amiloride-treated $\beta \mathrm{ENaC}$-overexpressing and wild-type mice (Figure E1) indicated that intranasally administered amiloride was at least partially absorbed, resulting in systemic effects including $\mathrm{ENaC}$ blockade in the kidney. To examine the possibility that therapeutic benefits of intranasal amiloride treatment (Figures 1 and 2) were caused by systemic rather than by topical inhibition of $\mathrm{ENaC}$ in the airways, we performed studies in which $\beta \mathrm{ENaC}$-overexpressing mice and wild-type littermates were treated systemically with subcutaneous injections of amiloride $(0.1 \mathrm{mmol} / \mathrm{l}$, dissolved in $\mathrm{NaCl} 0.9 \%$; $100 \mu \mathrm{l} / \mathrm{g}$ body weight; 3 times per day), or equal volumes of $\mathrm{NaCl}$ $0.9 \%$ alone, for a period of $2 \mathrm{wk}$. Of note, the dose of subcutaneously administered amiloride was equivalent to the total dose used in intranasal treatment studies (Figures 1 and 2). Systemic amiloride treatment caused more severe growth retardation in mice of both genotypes than topical treatment, but did not have therapeutic effects on pulmonary mortality, airway mucus obstruction, or goblet cell metaplasia in $\beta E N a C$-overexpressing mice (Figures E3A-E3D). Treatment with subcutaneous $\mathrm{NaCl} 0.9 \%$ alone also had no effect on the pulmonary phenotype in $\beta \mathrm{ENaC}$-overexpressing mice (Figure 1, and Figures E3A-E3D). 

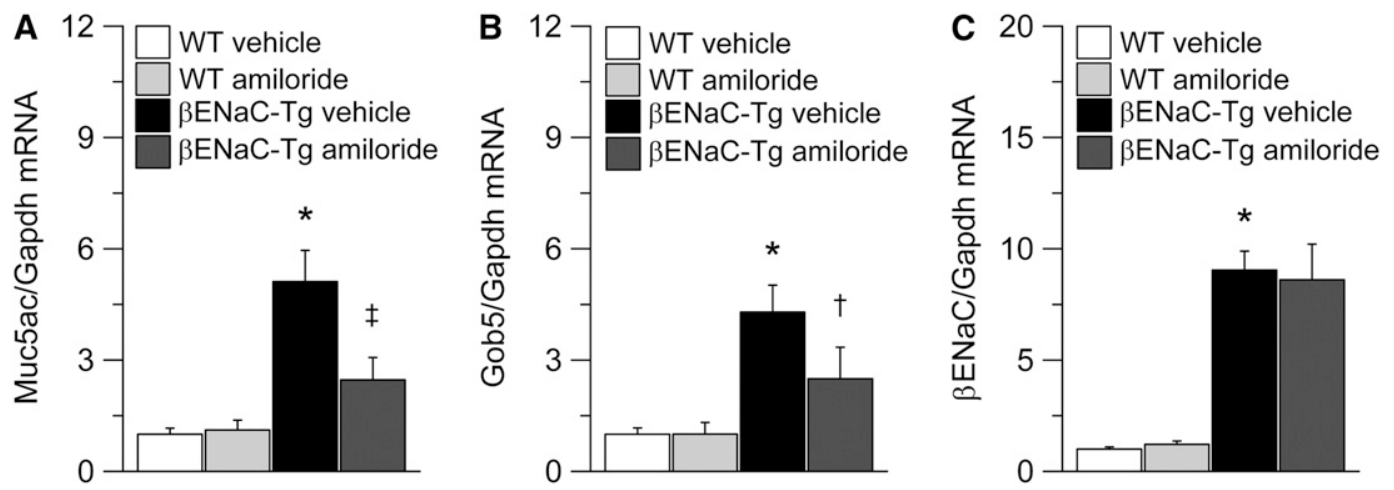

Figure 2. Preventive amiloride therapy reduces increased mucin expression in $\beta E N a C$ overexpressing mice. $(A-C)$ Expression levels of Muc5ac, Gob5, and $\beta \mathrm{ENaC}$ transcripts in lungs from wild-type and $\beta \mathrm{ENaC}$ overexpressing mice after 2 weeks of preventive amiloride treatment ( $\mathrm{n}=13-15$ mice for each group; ${ }^{*} p \leqslant 0.001$ compared with vehicle-treated wild-type, $\dagger p<0.05$ compared with vehicle-treated $\quad \beta E N a C$-overexpressing mice, $¥ P<0.01$ compared with vehicle-treated $\beta E N a C$-overexpressing mice).

\section{Amiloride Treatment Has No Effect on Mucus Obstruction, Goblet Cell Metaplasia and Mortality in $\beta E N a C$-overexpressing Mice with Established CF-like Lung Disease}

Based on the therapeutic benefits of preventive intranasal amiloride therapy, we next mimicked the paradigm of previous clinical trials in patients with CF $(20,21,29)$ and tested the effect of amiloride administration on mucus obstruction and mucus

hypersecretion in adult $\beta E N a C$-overexpressing mice with established CF-like lung disease. We started treatment at the age of 4 weeks, when $\beta E N a C$-overexpressing mice exhibit chronic airway mucus obstruction and remodeling with goblet cell metaplasia and epithelial hypertrophy $(15,17)$, and continued treatment of $\beta \mathrm{ENaC}$-overexpressing mice and their wild-type littermates by intranasal instillation of amiloride or vehicle alone for a period of

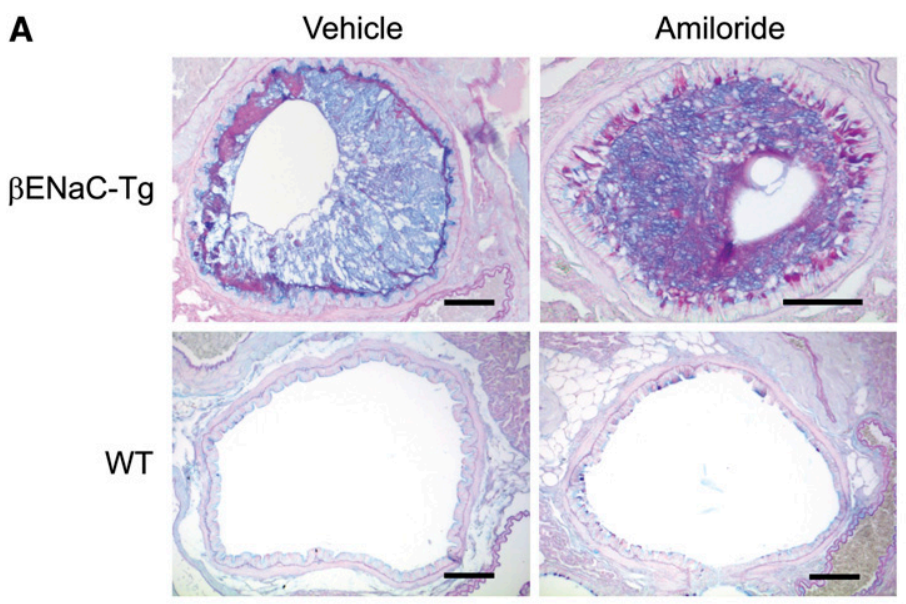

\section{B}
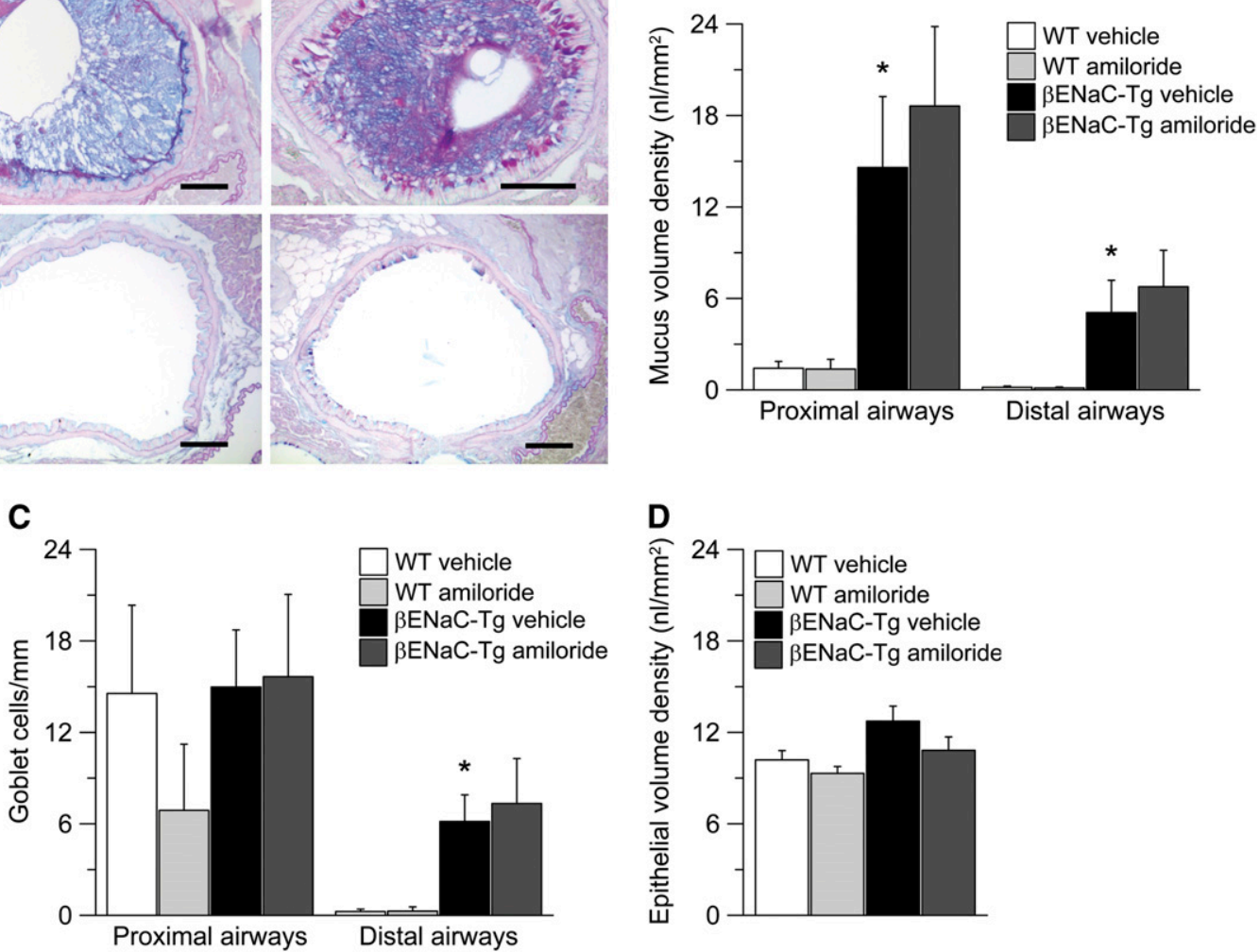

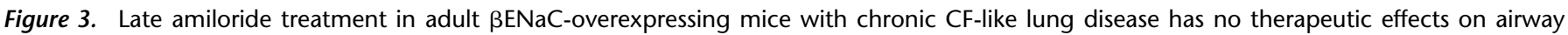

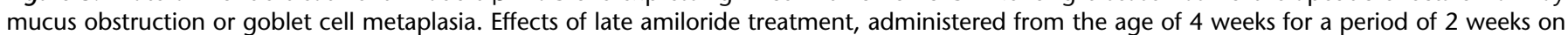

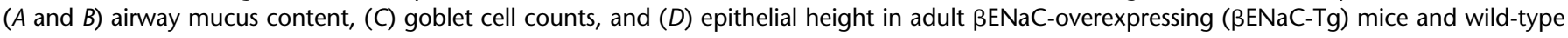

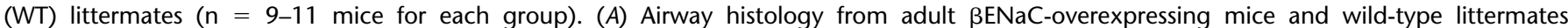

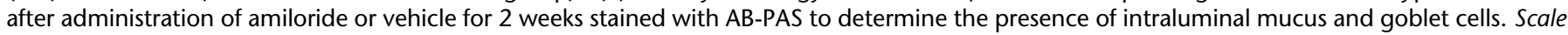

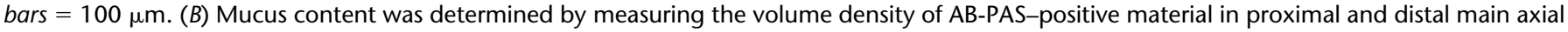

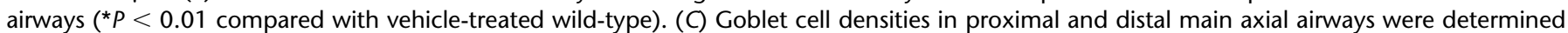

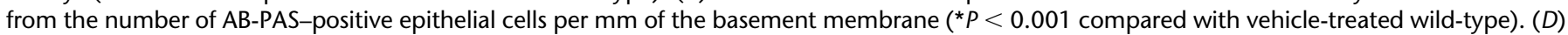
Epithelial height, as determined from measurement of epithelial volume density in main axial airways. 
2 weeks as for the preventive amiloride study (Figure 1). In contrast to preventive therapy, initiating amiloride treatment in adult mice reduced neither proximal nor distal airways mucus obstruction (Figures $3 \mathrm{~A}$ and 3B), nor goblet cell metaplasia (Figure 3C) and epithelial thickening (Figure 3D) in amiloridetreated versus vehicle-treated $\beta \mathrm{ENaC}$-overexpressing mice.

Because recent studies demonstrated that mucus plugging in $\beta \mathrm{ENaC}$-overexpressing mice originates in the trachea during the first week of life in the absence of goblet cell metaplasia and intrapulmonary mucus obstruction (17), we asked if amiloride therapy was still effective when treatment was started at the age of 5 days - that is, after the onset of proximal mucus plug formation, but before the establishment of chronic lung disease in $\beta E N a C$ overexpressing mice. In contrast to preventive therapy administered from the first day of life (Figure 1), initiating amiloride treatment in mice that were alive at the age of 5 days for a period of 2 weeks failed to reduce mortality in amiloride-treated versus vehicle-treated $\beta E N a C$-overexpressing mice (Figure 4A). Further, initiating amiloride treatment at the age of 5 days had no effect on airway mucus obstruction (Figure 4B), goblet cell metaplasia (Figure 4C), or epithelial thickening (Figure 4D) in $\beta E N a C$-overexpressing mice. Collectively, these data demon- strate that preventive amiloride treatment is effective in reducing airway mucus obstruction, airway remodeling, mucin hypersecretion, and pulmonary mortality (Figures 1 and 2), but that these therapeutic effects were abrogated when treatment was started after the onset of CF-like lung disease (Figures 3 and 4) in $\beta E N a C$-overexpressing mice.

\section{Preventive Amiloride Therapy Reduces Airway Inflammation in $\beta E N a C$-overexpressing Mice}

In addition to airway mucus obstruction and mucus hypersecretion, chronic airway inflammation is an invariable feature of $\mathrm{CF}$ lung disease, leading to progressive damage and remodeling of the lung (30-32). We, therefore, next asked if preventive intranasal amiloride therapy had therapeutic effects on airway inflammation in $\beta E N a C$-overexpressing mice. Consistent with a Th2-biased immune system in the neonatal period $(33,34)$, we have previously shown that spontaneous airway inflammation in 2 -week-old $\beta \mathrm{ENaC}$-overexpressing mice is predominated by eosinophils associated with morphologically activated macrophages (i.e., foam cells), elevated numbers of neutrophils, and increased levels of the Th2-signaling molecule IL-13 (17). Evaluation of BAL fluid for inflammatory cells at the end of the
A

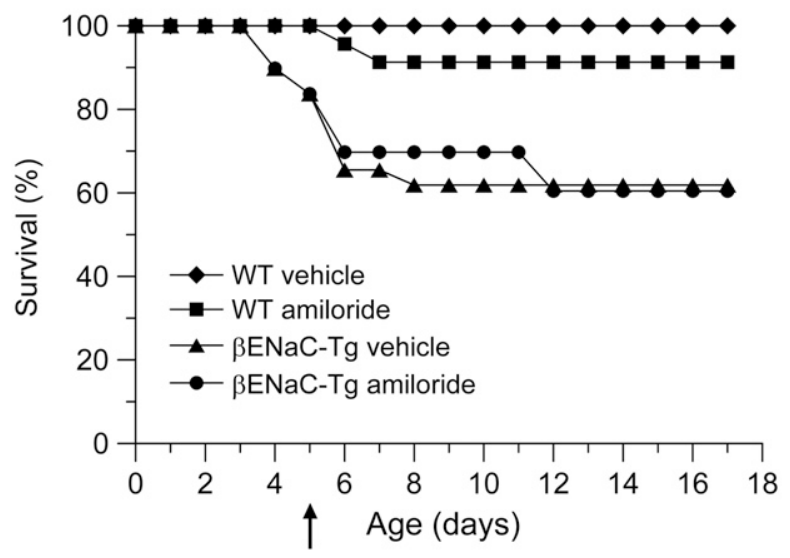

Start of treatment

C

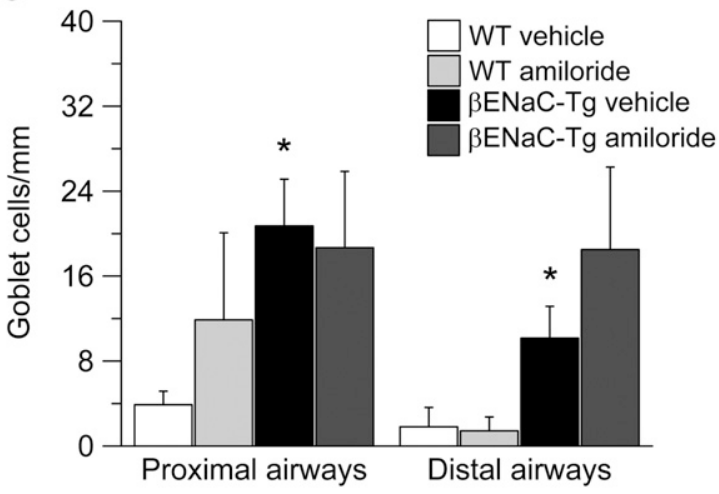

B
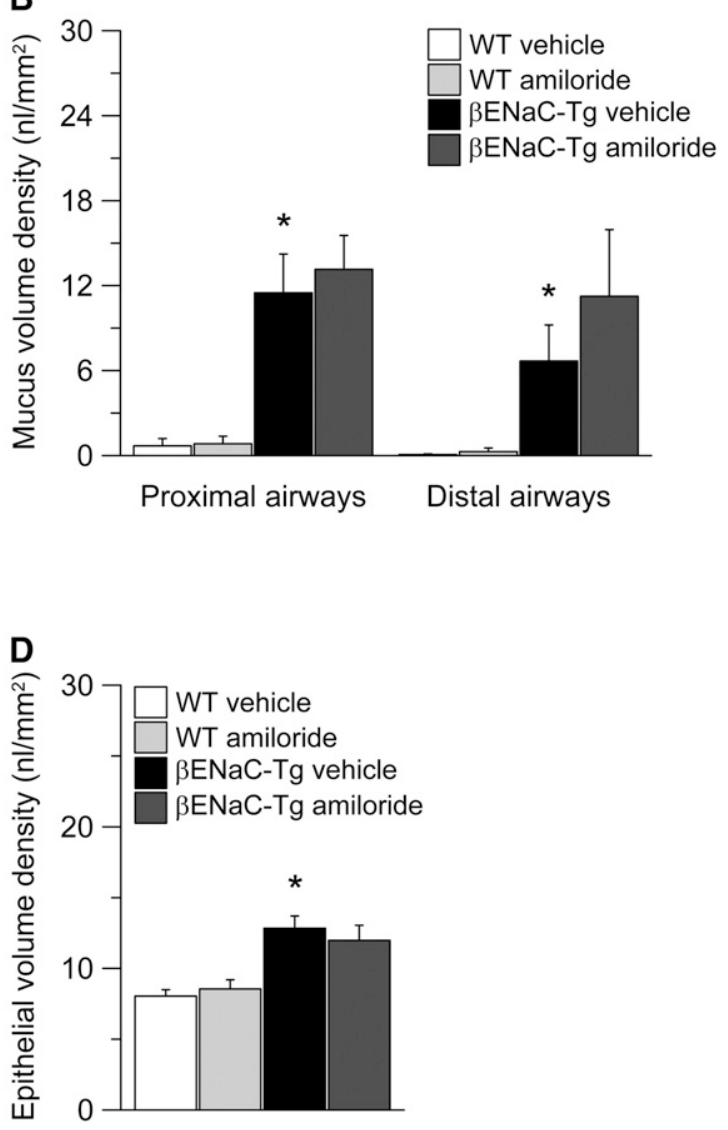

Figure 4. Initiating amiloride treatment in juvenile $\beta \mathrm{ENaC}$-overexpressing mice with established mucus plugging has no therapeutic effects on airway mucus obstruction, goblet cell metaplasia, or pulmonary mortality. Effect of amiloride treatment, administered from the age of 5 days for a period of 2 weeks on $(A)$ survival, $(B)$ airway mucus content, $(C)$ goblet cell counts, and $(D)$ epithelial height in juvenile $\beta E N a C$-overexpressing $(\beta E N a C-T g)$ mice and wild-type (WT) littermates. $(A)$ Survival curves for $\beta E N a C$-overexpressing and wild-type mice treated with amiloride or vehicle alone from the age of 5 days ( $n=18-34$ mice for each group). (B) Mucus content in proximal and distal main axial airways ( $n=7-11$ mice for each group; ${ }^{*} P<0.001$ compared with vehicle-treated wild-type). (C) Goblet cell counts in proximal and distal main axial airways ( $\mathrm{n}=7-11$ mice for each group; ${ }^{*} P<0.01$ compared with vehicle-treated wild-type). $(D)$ Epithelial volume density as a measure of epithelial height was determined in main axial airways ( $\mathrm{n}=7-11$ mice for each group; ${ }^{*} P<0.001$ compared with vehicle-treated wild-type). 
2-week treatment period revealed that total cells and eosinophil numbers were significantly reduced in amiloride-treated versus vehicle-treated $\beta E N a C$-overexpressing mice (Figures $5 \mathrm{~A}$ and $5 \mathrm{~B})$. Notably, total macrophage numbers were not changed, but macrophage activation was significantly reduced by preventive amiloride therapy in $\beta \mathrm{ENaC}$-overexpressing mice (Figures 5A$5 \mathrm{C})$. The reduction of airway eosinophilia was paralleled by a significant reduction in IL-13 levels in BAL from amiloridetreated versus vehicle-treated $\beta \mathrm{ENaC}$-overexpressing mice (Figure 5D). In wild-type littermates, preventive amiloride therapy did not have adverse effects on BAL cellularity, macrophage morphology, or IL-13 concentration (Figures 5A-5D).

In contrast to intranasal treatment, subcutaneous administration of amiloride had no effect on BAL inflammatory cell counts in $\beta \mathrm{ENaC}$ overexpressing mice (Figure E3E). Taken together, our results show that preventive topical inhibition of airway $\mathrm{Na}^{+}$hyperabsorption was efficient in reducing the chronic airway inflammation characteristic of the $\mathrm{CF}$-like lung disease in $\beta \mathrm{ENaC}$-overexpressing mice.

\section{Amiloride Treatment Has No Effect on Airway Inflammation in $\beta E N a C$-overexpressing Mice with Established CF-like Lung Disease}

Next, we evaluated the effects of amiloride intervention on airway inflammation in 5-day-old (Figures 6A, 6C, and 6E) and 4-weekold (Figures $6 \mathrm{~B}, 6 \mathrm{D}$, and $6 \mathrm{~F}$ ) $\beta \mathrm{ENaC}$-overexpressing mice with established CF-like lung disease $(15,17)$. In contrast to the antiinflammatory effects provided by preventive amiloride therapy, starting amiloride treatment after the onset of lung disease had no effect on elevated BAL inflammatory cell counts (Figures 6A and 6B), morphologic macrophage activation (Figures $6 \mathrm{C}$ and $6 \mathrm{D}$ ), or IL-13 levels in BAL (Figures 6E and 6F) from amiloridetreated versus vehicle-treated $\beta \mathrm{ENaC}$-overexpressing mice.
Therapeutic Effects of Preventive Amiloride Treatment Were Not Sustained if Treatment Was Discontinued in BENaC-overexpressing Mice

Next, we performed amiloride withdrawal studies to determine if therapeutic effects of preventive amiloride treatment (Figures 1 and 5) were sustained, or if airway mucus obstruction and airway inflammation recurred, when amiloride treatment was stopped in $\beta \mathrm{ENaC}$-overexpressing mice. In these studies, amiloride or vehicle alone were applied from the first day of life for a period of 2 weeks as described for the experiments shown in Figures 1 and 5. Then treatment was discontinued, mice were monitored for survival, and BAL was performed and lungs of mice from all treatment groups were evaluated for mucus obstruction at the age of 6 weeks. Withdrawal of amiloride treatment did not cause recurrence of mortality in $\beta \mathrm{ENaC}$-overexpressing mice (data not shown). However, the severity of airway mucus obstruction, goblet cell metaplasia, epithelial hypertrophy, and BAL inflammatory cell counts were not different in $\beta \mathrm{ENaC}$-overexpressing mice that were temporarily treated with either amiloride or vehicle alone (Figure 7). These results demonstrate that early but temporary amiloride therapy reduced neonatal mortality, but did not have sustained therapeutic effects on mucus obstruction and airway inflammation in $\beta \mathrm{ENaC}$-overexpressing mice.

\section{Preventive Amiloride Therapy Reduces Epithelial Necrosis in BENaC-overexpressing Mice}

The mechanistic links between increased epithelial $\mathrm{Na}^{+}$absorption, reduced ASL volume, and airway inflammation in the $\beta \mathrm{ENaC}$-overexpressing mouse are likely multiple. One clue to such a link emanates from recent studies that demonstrated that neonatal (but not 4 -wk-old) $\beta E N a C$-overexpressing mice develop airway epithelial hypoxia and epithelial cell necrosis, likely
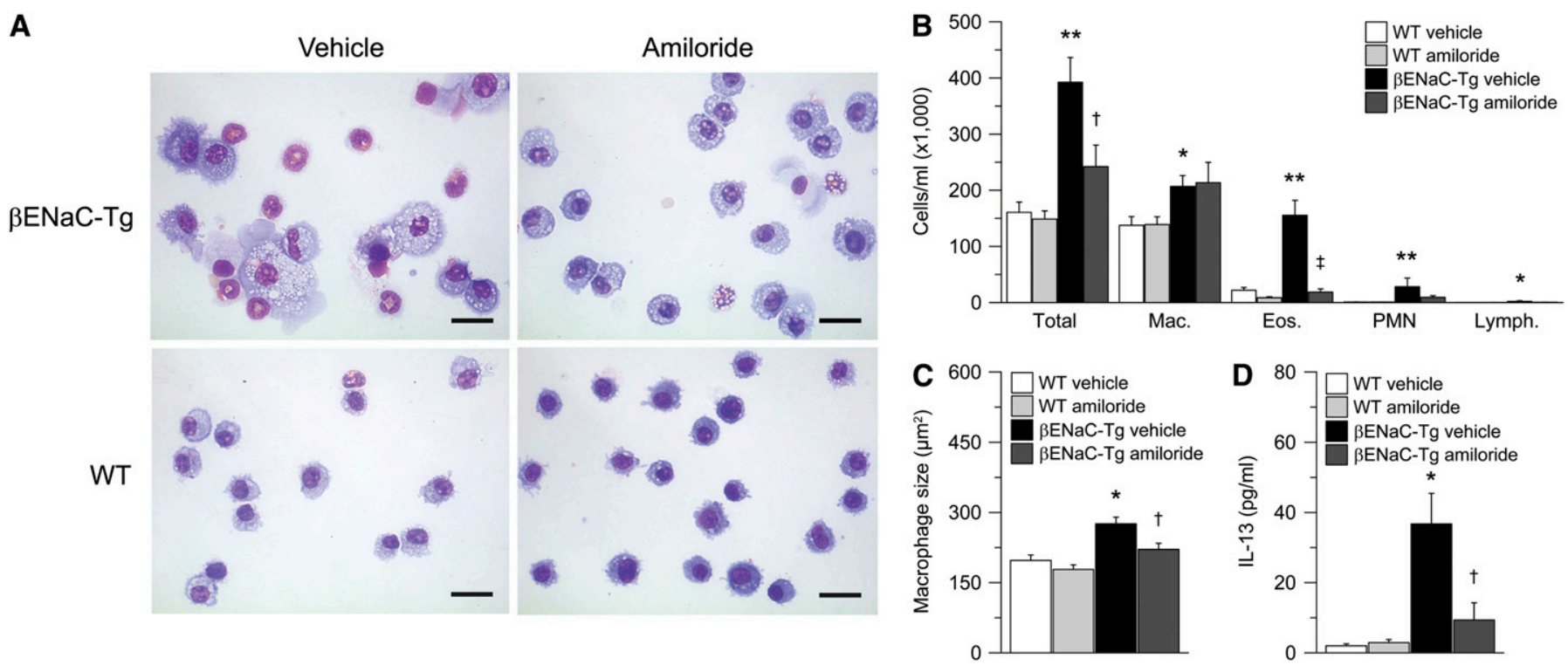

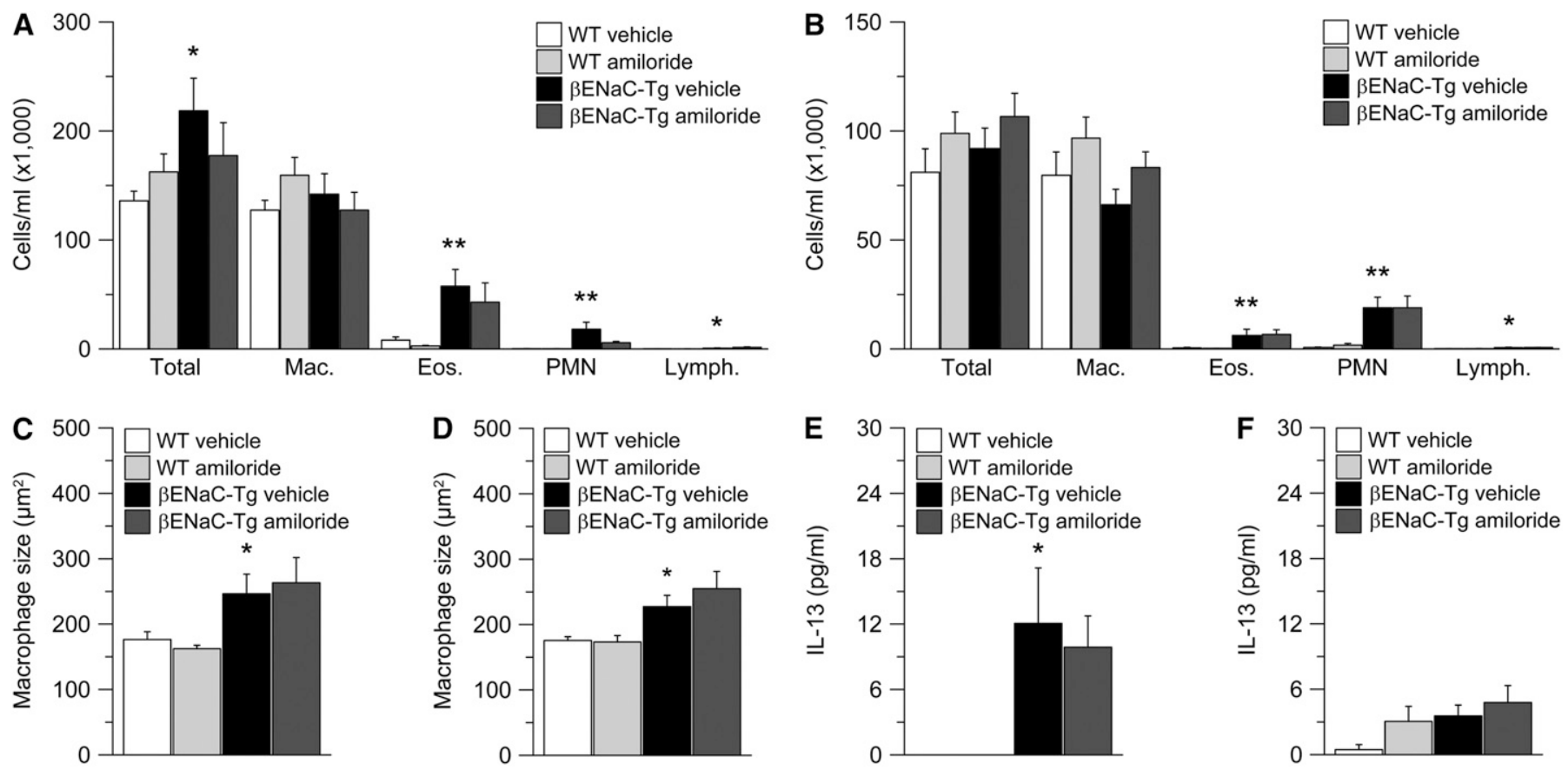

Figure 6. Late amiloride therapy has no effect on airway inflammation in $\beta E N a C$-overexpressing mice. ( $A-E$ ) Effect of late amiloride treatment, administered from the age of $(A, C$, and $E) 5$ days or $(B, D$, and $F) 4$ weeks for a period of 2 weeks, on $(A$ and $B)$ cell counts, $(C$ and $D)$ macrophage size, and $(E$ and $F)$ IL-13 concentrations in BAL from $\beta E N a C$-overexpressing and wild-type mice. $(A$ and $B)$ BAL cell counts after treatment with amiloride or vehicle alone from the age of $(A) 5$ days or $(B) 4$ weeks $\left(\mathrm{n}=13-34\right.$ mice for each group; ${ }^{*} P<0.01$ compared with vehicle-treated wildtype, ${ }^{* *} P<0.001$ compared with vehicle-treated wild-type). ( $C$ and $D$ ) Size of BAL macrophages after treatment from $(C) 5$ days or $(D) 4$ weeks $(\mathrm{n}=$ 7-11 mice for each group; ${ }^{*} P<0.05$ compared with vehicle-treated wild-type). ( $E$ and $F$ ) IL-13 concentration in BAL after treatment from ( $E$ ) 5 days or $(F) 4$ weeks ( $\mathrm{n}=4-17$ mice for each group; ${ }^{*} P<0.01$ compared with vehicle-treated wild-type).

resulting from combined effects of increased epithelial $\mathrm{O}_{2}$ consumption due to $\mathrm{Na}^{+}$hyperabsorption and decreased $\mathrm{O}_{2}$ delivery due to airway mucus plugging (17). Because necrotic debris is a consistent finding in the small airways of patients with CF (35), and cellular necrosis is a potent trigger for inflammation (36), we evaluated the effects of preventive amiloride treatment starting on the first day of life on the occurrence of necrotic epithelial cells in airways of 3-day-old $\beta E N a C$-overexpressing neonates (Figure 8). Notably, compared with vehicle treatment, preventive administration of amiloride significantly reduced the frequency of necrotic airway epithelial cells in neonatal $\beta E N a C$-overexpressing mice (Figures $8 \mathrm{~A}$ and $8 \mathrm{~B}$ ), demonstrating that preventive $\mathrm{ENaC}$ blocker therapy protected epithelial cells from necrosis and, thus, reduced a strong stimulus for airway inflammation.

\section{DISCUSSION}

In the present study, we used the $\beta \mathrm{ENaC}$-overexpressing mouse as a model of $\mathrm{CF}$ lung disease $(15,16)$ to test the timing of strategies that inhibit increased ENaC-mediated airway $\mathrm{Na}^{+}$ absorption to treat $\mathrm{CF}$ lung disease in vivo. Our results show for the first time that preventive inhibition of accelerated $\mathrm{Na}^{+}$ absorption by the ENaC blocker amiloride is an effective therapy for CF-like lung disease in a murine disease model. Preventive amiloride administration exhibited significant therapeutic benefits by reducing airway mucus obstruction, goblet cell metaplasia, mucus hypersecretion, airway epithelial necrosis, and pulmonary inflammation in $\beta E N a C$-overexpressing mice (Figures 1, 2, 5, and 8 ). These therapeutic benefits resulted in an approximately $70 \%$ reduction in spontaneous pulmonary mortality, and provide a proof of concept for a novel therapeutic strategy for CF lung disease (Figures 1, 2, 5, and 8). In contrast to currently available $\mathrm{CF}$ therapies that target secondary pathogenetic events (i.e., antiinfective compounds for the treatment of bacterial infections $[32,37]$ and inhaled DNase to antagonize increases in sputum viscoelasticity caused by high levels of DNA released from inflammatory cells $[38,39]$ ), preventive inhibition of increased $\mathrm{Na}^{+}$ absorption constitutes a pharmacologic strategy that targets a proximal mechanism involved in the pathogenesis of CF lung disease.

We used the $\beta E N a C$-overexpressing mouse for these studies because previous work demonstrated that CF mice, either deficient of CFTR or carrying specific CFTR mutations, do not mimic increased $\mathrm{Na}^{+}$absorption in the lower airways and do not develop spontaneous airway mucus plugging, goblet cell metaplasia, and airway inflammation characteristic of CF lung disease in humans $(8,10,40,41)$. Therefore, $\mathrm{CF}$ mice were not directly useful for preclinical evaluation of $\mathrm{ENaC}$ directed therapies in $\mathrm{CF}$ lung disease. However, besides dysregulation of cAMP-dependent $\mathrm{Cl}^{-}$secretion and ENaC-mediated $\mathrm{Na}^{+}$absorption, CFTR deficiency and/or malfunction has been implicated in various other cellular dysfunctions, including abnormal receptor-mediated clearance of bacteria, phagosome acidification in macrophages, cellular lipid trafficking, and ceramide metabolism (42$46)$. Because CFTR function is normal in $\beta \mathrm{ENaC}$-overexpressing mice, efficient therapy of CF lung disease may be more complex in humans, and may require correction of other cellular dysfunctions in addition to increased airway $\mathrm{Na}^{+}$absorption. The development of compounds that correct and/or potentiate dysfunctional CFTR (47-49) will help elucidate the relative importance of increased airway $\mathrm{Na}^{+}$absorption versus defects in other CFTR-mediated functions as targets for CF pharmacotherapy.

Interestingly, in addition to mucolytic effects, preventive amiloride therapy had potent effects on airway inflammation in $\beta E N a C$-overexpressing mice (Figure 5). We speculate that the antiinflammatory effects of amiloride may be mediated by several mechanisms. First, we previously hypothesized that chronic 
A

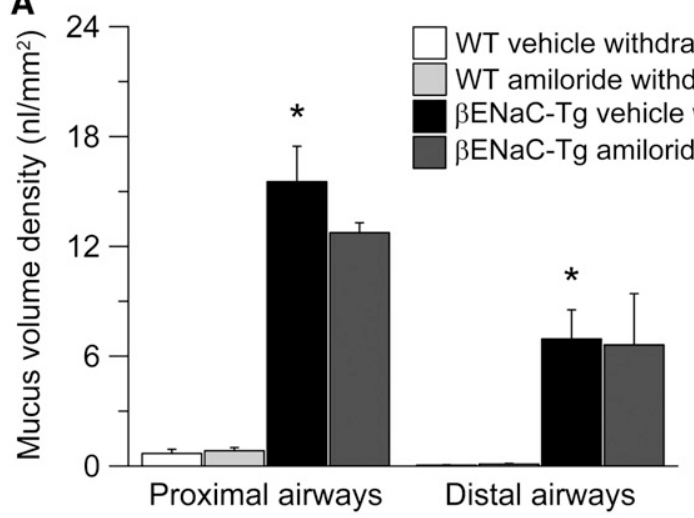

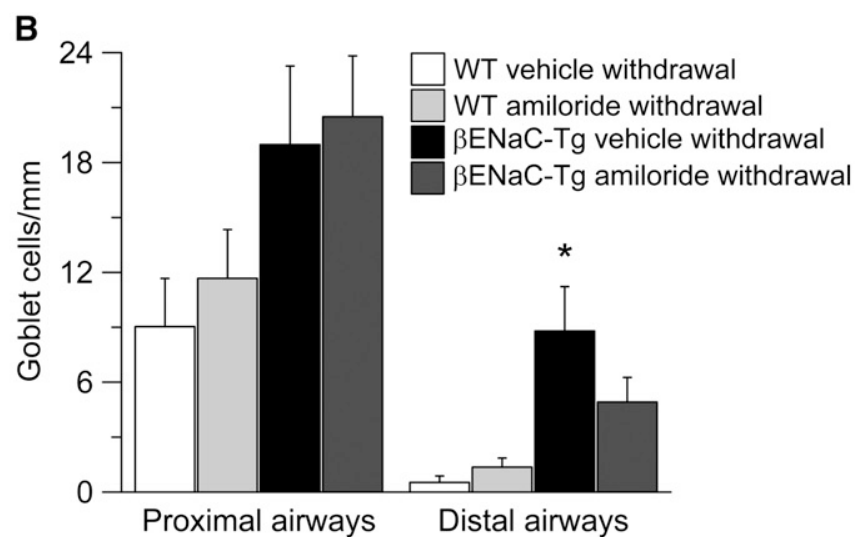

C

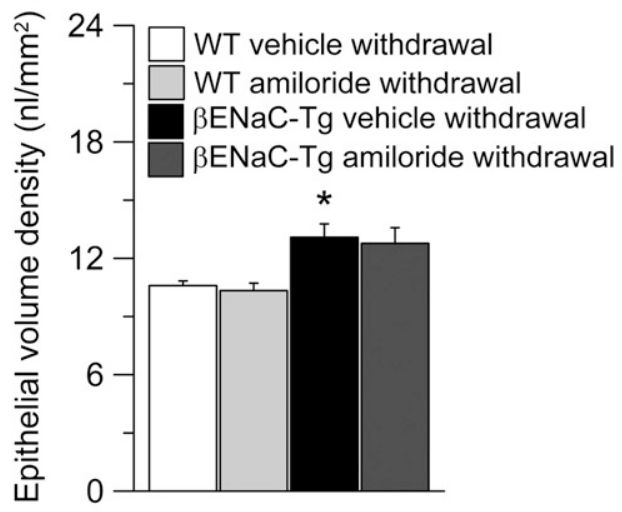

D

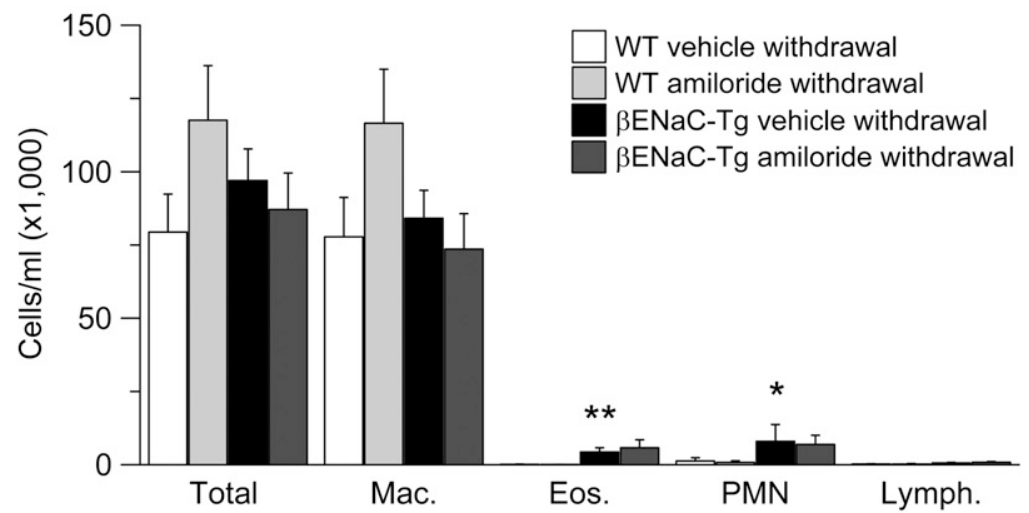

Figure 7. Therapeutic effects of preventive amiloride treatment are not sustained if treatment is withdrawn in $\beta \mathrm{ENaC}$-overexpressing mice. Summary of amiloride withdrawal studies. $\beta \mathrm{ENaC}$-overexpressing ( $\beta \mathrm{ENaC}-\mathrm{Tg}$ ) mice and wild-type (WT) littermates were treated with amiloride from birth for a period of $2 \mathrm{wk}$, then treatment was withdrawn and effects on $(A)$ airway mucus content, $(B)$ goblet cell counts, $(C)$ epithelial height, and $(D)$ inflammatory cell counts were evaluated in 6-week-old adult mice $(\mathrm{n}=6-10$ mice for each group). ( $A$ ) Mucus content in proximal and distal main axial airways ( ${ }^{*} P \leqslant 0.001$ compared with vehicle-treated wild-type). (B) Goblet cell counts in proximal and distal main axial airways $\left({ }^{*} P<0.05\right.$ compared with vehicle-treated wild-type). (C) Epithelial height was determined by measuring epithelial volume density in main axial airways $\left({ }^{\star} P<\right.$ 0.05 compared with vehicle-treated wild-type). (D) Total and differential BAL cell counts $\left({ }^{\star} P<0.05\right.$ compared with vehicle-treated wild-type, ${ }^{* \star} P \leqslant$ 0.001 compared with vehicle-treated wild-type).

airway inflammation may be triggered by a failure to clear inhaled particulates and irritants, which induce expression of proinflammatory cytokines like keratinocyte chemoattractant $(\mathrm{KC})$ by macrophages and/or airway epithelia in $\beta E N a C$-overexpressing mice $(15,50)$. We therefore predict that antiinflammatory effects may be conferred by improved clearance of proinflammatory stimuli when airway $\mathrm{Na}^{+}$hyperabsorption and ASL depletion were prevented by amiloride. Second, we recently demonstrated that neonatal $\beta E N a C$-overexpressing mice develop airway epithelial necrosis, likely reflecting increased epithelial $\mathrm{O}_{2}$ consumption due to $\mathrm{ENaC}$-mediated $\mathrm{Na}^{+}$hyperabsorption and/or decreased $\mathrm{O}_{2}$ delivery due to airway mucus plugging (17). Because necrosis is a strong trigger for inflammation (36), we predict that inhibition of this phenotype by preventive amiloride shown in this study (Figure 8) also reduced a potent stimulus for airway inflammation in $\beta E N a C$-overexpressing mice. Third, amiloride has been shown to inhibit secretion of proinflammatory cytokines including IL-8 and TNF- $\alpha$ in alveolar macrophages, and that this antiinflammatory action is mediated by inhibition of the $\mathrm{Na}^{+} / \mathrm{H}^{+}$exchanger (NHE) (51), rather than by ENaC blockade. Future studies with more selective blockers $(51,52)$ are required to determine the relative roles of $\mathrm{ENaC}$ versus NHE as targets for antiinflammatory therapy of CF-like lung disease in $\beta E N a C$-overexpressing mice.
Our observation that amiloride therapy became ineffective when treatment was started after the onset of CF-like lung disease in $\beta \mathrm{ENaC}$-overexpressing mice (Figures 3, 4, and 6) is consistent with previous clinical trials in patients with established CF lung disease $(20,21)$. The failure of amiloride inhalation therapy in patients with CF was mainly attributed to: (1) insufficient pulmonary delivery of amiloride due to limited solubility restricting the amount that could be delivered by a nebulizer; (2) limited potency; and (3) limited half-life of amiloride on airway surfaces (53-55). Our findings showing that amiloride can be delivered to the lung in therapeutically active quantities before the onset of lung disease suggest that airway mucus obstruction and/or airway remodeling were contributing factors to the absence of therapeutic benefits in older $\beta \mathrm{ENaC}$-overexpressing mice and patients with $\mathrm{CF}$ with established lung disease.

In this context, previous studies demonstrated that single viral infections of the respiratory tract not only cause acute bronchiolitis, but can also trigger chronic responses with goblet cell metaplasia and mucus hypersecretion that persist for many years after viral clearance (56). Emerging evidence suggests that persisting airway disease may be caused by viral reprogramming of the epithelium and/or components of the innate and adaptive immune system in a susceptible host, and that this mechanism may be implicated in the pathogenesis of chronic airway diseases 


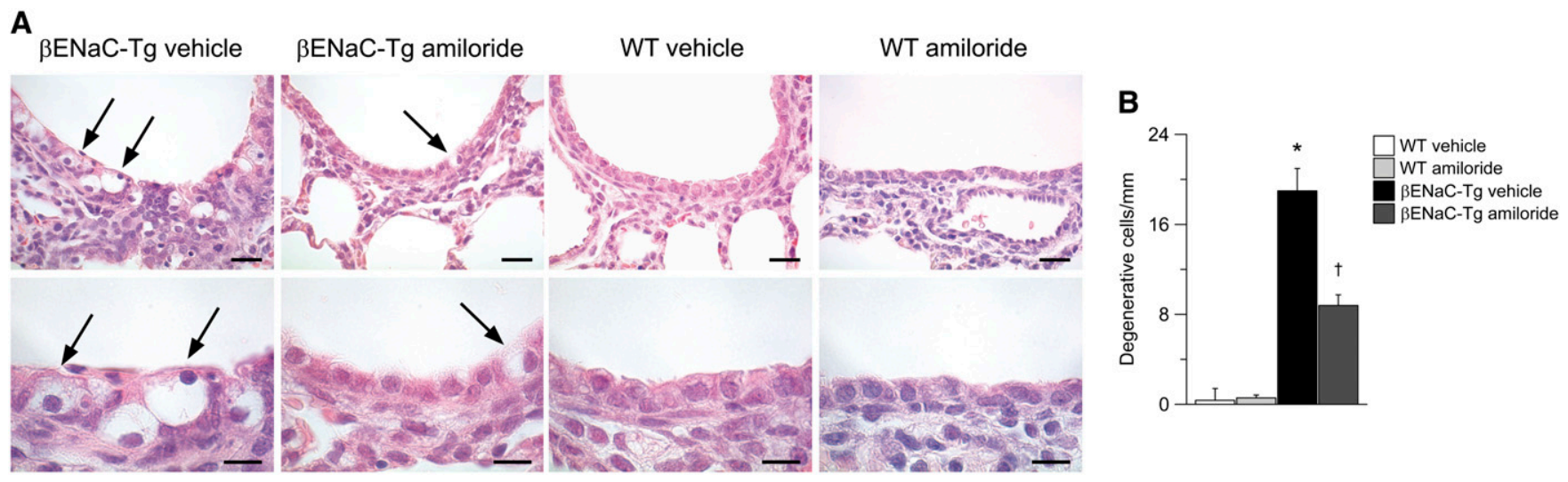

Figure 8. Preventive amiloride therapy reduces airway epithelial necrosis in $\beta E N a C$-overexpressing mice. Effect of preventive amiloride treatment, administered from the first day of life for a period of 3 days, on $(A)$ airway histology and $(B)$ numbers of degenerative airway epithelial cells in $\beta E N a C$ overexpressing ( $\beta \mathrm{ENaC}$-Tg) mice and wild-type (WT) littermates. ( $A$ ) Airway histology of 3 -day-old $\beta E N a C$-overexpressing and wild-type mice after preventive treatment with amiloride or vehicle alone. Sections were stained with hematoxylin and eosin to determine the numbers of degenerative airway epithelial cells (arrows). Representative of $n=7-12$ mice for each group. Scale bars $=20 \mu \mathrm{m}$ (upper panels) or $10 \mu \mathrm{m}$ (lower panels). (B) Severity of airway epithelial necrosis was determined from the number of degenerative epithelial cells per mm of the basement membrane $(\mathrm{n}=7-$ 12 mice for each group; ${ }^{*} P \leqslant 0.001$ compared with vehicle-treated wild-type, ${ }^{\dagger} p<0.001$ compared with vehicle-treated $\beta$ ENaC-overexpressing mice).

such as asthma and chronic bronchitis $(56,57)$. We speculate that early mucus obstruction and inflammation caused by ASL depletion in CF lung disease may provide an alternative stimulus that reprograms host cell behavior to produce chronic airway disease. While future studies are required to elucidate the mechanisms that impede therapeutic effects of amiloride in $\beta \mathrm{ENaC}$-overexpressing mice and patients with $\mathrm{CF}$ with established airway disease, our results point to the possibility that a preventive $\mathrm{ENaC}$ blocker treatment paradigm may be required for effective therapy of CF lung disease.

The concept that a single viral infection in a vulnerable period could trigger prolonged airways disease (56) led us to speculate that the lung disease in adult $\beta E N a C$-overexpressing mice may reflect a sustained change in airway cell populations and/or function that resulted from early $(3-10 \mathrm{~d})$ pathologic events (17). We, therefore, tested the hypothesis that early inhibition of airway epithelial dysfunction by preventive ENaC blocker therapy may have durable effects by performing amiloride withdrawal protocols, in which preventive amiloride therapy was discontinued in juvenile mice and lungs were evaluated after a 4-week off treatment period. These studies demonstrated that stopping amiloride therapy resulted in recurrence of airway mucus obstruction, epithelial remodeling, and airway inflammation in adult $\beta E N a C$-overexpressing mice (Figure 7) (17). However, withdrawal of amiloride treatment in surviving juvenile $\beta E N a C$ overexpressing mice did not cause recurrence of mortality. Our previous studies demonstrated that death in neonatal $\beta \mathrm{ENaC}$ overexpressing mice is caused by severe mucus plugging of the trachea (17). We speculate that the growth-related increase in cross-sectional surface area of the trachea protected juvenile $\beta \mathrm{ENaC}$-overexpressing mice from life-threatening airflow limitation after amiloride therapy was discontinued and mucus accumulation recurred. Taken together, the observation that temporary inhibition of increased airway $\mathrm{Na}^{+}$absorption prevented early mortality, but did not have lasting therapeutic effects on airway mucus obstruction and inflammation in $\beta E N a C$-overexpressing mice, suggests that continuous $\mathrm{ENaC}$ blocker therapy may be required to optimize long-term treatment benefits in CF lung disease.

Regarding the feasibility of preventive amiloride therapy in patients with $\mathrm{CF}$, only limited information is available on the timing of the onset and early progression of CF lung disease in humans. Pathologic studies demonstrated that lungs were structurally normal in CF neonates who died of intestinal obstruction, but that airway mucus plugging associated with air trapping and atelectasis developed in the first months of life $(58,59)$. These findings suggest that inhaled amiloride therapy is unlikely to be beneficial for patients with $\mathrm{CF}$ who are diagnosed in infancy or early childhood on the basis of clinical symptoms. On the other hand, these pathologic studies indicate that in the first weeks and months of life, there is a window for preventive therapy in the human CF lung. Importantly, recent developments in $\mathrm{CF}$ neonatal screening allow establishing a $\mathrm{CF}$ diagnosis in this critical life span $(60,61)$. We, therefore, predict that near-birth initiation of preventive amiloride therapy may become feasible in a larger number of patients with $\mathrm{CF}$ in the near future.

Previous pharmacokinetic studies in healthy subjects demonstrated that targeting the lung with aerosols produced therapeutic amiloride concentrations on airway surfaces in a structurally normal lung $(53,62)$. Importantly, previous clinical studies documented that long-term inhalation of aerosolized amiloride at concentrations of 1 to $10 \mathrm{mmol} / \mathrm{L}$ (equivalent to doses of 0.1 to 1 $\mathrm{mg} / \mathrm{kg}$ body weight per day), was well tolerated, safe, and did not cause diuresis or electrolyte imbalance in humans $(20,21,29)$. In mice, intranasal instillation is commonly used for pulmonary delivery of drugs or allergens (63). Pulmonary delivery is likely mediated by generation of an aerosol within the nose, which is deposited onto the lower airways. Our deposition studies indicated that intranasal instillation in mice produced a pulmonary deposition fraction $(\sim 4 \%)$ that was substantially smaller than that achieved by aerosol inhalation in humans (Figure E1) $(20,21$, 29, 53, 64, 65). Further, initial dose-response studies indicated that high doses of intranasal amiloride $(\sim 8 \mathrm{mg} / \mathrm{kg}$ body weight per day) were required to reduce pulmonary mortality in neonatal $\beta \mathrm{ENaC}$-overexpressing mice (Figure E2). These results indicate that the high intranasal amiloride dose administered in our study was required to compensate for inefficient intrapulmonary deposition. The diuretic effects caused by intranasal amiloride instillation in mice (Figure E1) indicated that much of the intranasally deposited amiloride was swallowed and absorbed from the gastrointestinal tract, causing systemic effects by inhibition of $\mathrm{ENaC}$ in the kidney. 
Gastrointestinal absorption, therefore, can account for the diuretic effects, but also raised the possibility that therapeutic effects of intranasal amiloride therapy in $\beta \mathrm{ENaC}$-overexpressing mice (Figures 1 and 2) were mediated by systemic, rather than topical, ENaC inhibition in airway epithelia. To address this possibility, we treated mice systemically by subcutaneous amiloride injections with doses equivalent to the doses used for intranasal therapy (Figure E3). In these studies, preventive systemic amiloride treatment caused more severe weight loss, likely due to profound diuresis, but did not have therapeutic effects on the lung disease in $\beta E N a C$-overexpressing mice. Taken together, these findings support the concept that therapeutic benefits of preventive intranasal amiloride in $\beta E N a C$-overexpressing mice were conferred by topical blockade of ENaC in the airways, and predict that substantially lower doses will be required to deliver amiloride in pharmacologically active concentrations to the lungs of $\mathrm{CF}$ infants with efficient aerosol delivery systems $(64,65)$.

The low potency of amiloride and its short half-life on airway surfaces limited the ability of our studies, as well as previous clinical trials $(20,21)$, to address whether ENaC-directed therapies can be beneficial in established CF lung disease (53-55). These limitations have led to the development of a series of novel more potent and durable amiloride analogs designed specifically for inhalation therapy of CF lung disease $(52,66)$. Recent in vitro studies demonstrated that the selected compound 552-02 was 60to 100 -fold more potent, up to fivefold less reversible, and twofold more slowly absorbed from surfaces of airway epithelia than amiloride (52). Compared with amiloride, compound 552-02 produced greater ASL expansion in airway cultures in vitro and was more effective at increasing mucus clearance in sheep. These results indicate that highly potent and long-acting $\mathrm{ENaC}$ blockers may be more effective than amiloride, both in the prevention and therapy of CF lung disease. We predict that future studies in $\beta E N a C$-overexpressing mice will help to evaluate the efficacy and safety of these compounds, including their therapeutic effects in established lung disease, at the preclinical level.

As novel chemical entities, compounds such as 552-02 will first have to undergo preclinical evaluation and toxicity testing and are, therefore, years away from routine clinical use, especially for preventive therapy in very young patients with $\mathrm{CF}$. In contrast, amiloride is inexpensive, readily available, and has been in clinical use as a diuretic for many years. We predict that these properties, together with a widespread implementation of $\mathrm{CF}$ newborn screening programs $(60,61)$, and recent improvements in nebulizer technology allowing enhanced aerosol delivery to the neonatal and infant human lung $(64,65)$, may facilitate the translation of preventive amiloride therapy for CF lung disease from mice to the clinic.

We hypothesized that the predominant eosinophilic airway inflammation observed in juvenile (2- to 3-wk-old) $\beta E N a C$ overexpressing mice was triggered by impaired clearance of inhaled airborne allergens in a Th2-biased host $(17,33,34)$. Here, we demonstrate that characteristic features of this allergic airway inflammation, including airway eosinophilia and elevated IL-13, were effectively reduced by preventive amiloride therapy. Furthermore, recent evidence indicated that exposure to cigarette smoke decreases CFTR expression and cAMP-dependent $\mathrm{Cl}^{-}$ secretion in airway epithelia in vivo, suggesting that ASL depletion may also be implicated in the pathogenesis of reduced airway mucus clearance observed in smokers and patients with chronic bronchitis (67-69). In summary, our results suggest that improving ASL hydration by preventive inhalation therapy with the ENaC blocker amiloride may be of benefit for the treatment of $\mathrm{CF}$, and potentially other chronic lung diseases associated with mucociliary dysfunction, including chronic bronchitis and asthma.
Conflict of Interest Statement: Z.Z. does not have a financial relationship with a commercial entity that has an interest in the subject of this manuscript; D.T. does not have a financial relationship with a commercial entity that has an interest in the subject of this manuscript; S.C.S. does not have a financial relationship with a commercial entity that has an interest in the subject of this manuscript; $\mathrm{M}$.H. does not have a financial relationship with a commercial entity that has an interest in the subject of this manuscript; I.S. does not have a financial relationship with a commercial entity that has an interest in the subject of this manuscript; S.H. does not have a financial relationship with a commercial entity that has an interest in the subject of this manuscript; J.D. does not have a financial relationship with a commercial entity that has an interest in the subject of this manuscript; R.C.B. is named as a co-inventor on a patent filed on the $\beta E N a C$ overexpressing mouse in 2004; M.A.M. is listed on a patent application filed by the University of North Carolina at Chapel Hill, describing the $\beta E N a C$-overexpressing mouse. Of note, the $\beta E N a C$-overexpressing mouse has been deposited at JAX for general disposition.

Acknowledgment: The authors thank Dr. Jochen Ludwig (Department of Internal Medicine I and Clinical Chemistry, University of Heidelberg) for assistance in analyzing serum and urine electrolyte concentrations; Dr. Jack R. Harkema (Department of Pathobiology and Diagnostic Investigation, Michigan State University) for discussions and advise on morphometric analyses; and Dr. Andreas Kulozik for general support.

\section{References}

1. Kerem B, Rommens JM, Buchanan JA, Markiewicz D, Cox TK, Chakravarti A, Buchwald M, Tsui LC. Identification of the cystic fibrosis gene: genetic analysis. Science 1989;245:1073-1080.

2. Welsh MJ, Ramsey BW, Accurso F, Cutting GR. Cystic fibrosis. In: Scriver CR, Beaudet AL, Sly WS, Valle D, editors. The metabolic and molecular bases of inherited disease, 8th ed. New York: McGrawHill; 2001. pp. 5121-5188.

3. Anderson MP, Gregory RJ, Thompson S, Souza DW, Paul S, Mulligan RC, Smith AE, Welsh MJ. Demonstration that CFTR is a chloride channel by alteration of its anion selectivity. Science 1991;253:202205.

4. Canessa CM, Schild L, Buell G, Thorens B, Gautschl I, Horisberger JD, Rossier BC. Amiloride-sensitive epithelial $\mathrm{Na}^{+}$channel is made of three homologous subunits. Nature 1994;367:463-467.

5. Stutts MJ, Canessa CM, Olsen JC, Hamrick M, Cohn JA, Rossier BC, Boucher RC. CFTR as a cAMP-dependent regulator of sodium channels. Science 1995;269:847-850.

6. Mall M, Hipper A, Greger R, Kunzelmann K. Wild type but not $\Delta$ F508 CFTR inhibits $\mathrm{Na}^{+}$conductance when coexpressed in Xenopus oocytes. FEBS Lett 1996;381:47-52.

7. Letz B, Korbmacher C. cAMP stimulates CFTR-like $\mathrm{Cl}^{-}$channels and inhibits amiloride-sensitive $\mathrm{Na}^{+}$channels in mouse CCD cells. Am J Physiol 1997;272:C657-C666.

8. Knowles MR, Gatzy JT, Boucher RC. Increased biolelectric potential difference across respiratory epithelia in cystic fibrosis. $N$ Engl J Med 1981;305:1489-1495.

9. Knowles MR, Stutts MJ, Spock A, Fischer N, Gatzy JT, Boucher RC. Abnormal ion permeation through cystic fibrosis respiratory epithelium. Science 1983;221:1067-1070.

10. Boucher RC, Stutts MJ, Knowles MR, Cantley L, Gatzy JT. Na ${ }^{+}$ transport in cystic fibrosis respiratory epithelia. Abnormal basal rate and response to adenylate cyclase activation. J Clin Invest 1986;78: 1245-1252.

11. Mall M, Bleich M, Greger R, Schreiber R, Kunzelmann K. The amiloride inhibitable $\mathrm{Na}^{+}$conductance is reduced by CFTR in normal but not in cystic fibrosis airways. J Clin Invest 1998;102:15-21.

12. Matsui H, Grubb BR, Tarran R, Randell SH, Gatzy JT, Davis CW, Boucher RC. Evidence for periciliary liquid layer depletion, not abnormal ion composition, in the pathogenesis of cystic fibrosis airways disease. Cell 1998;95:1005-1015.

13. Mall M, Boucher RC. Pathogenesis of pulmonary disease in cystic fibrosis. In: Bush A, Alton E, Davies J, Griesenbach U, Jaffe A, editors. Cystic fibrosis in the 21st century. Basel: Karger; 2006. pp. $116-121$.

14. Livraghi A, Mall M, Paradiso AM, Boucher RC, Pedrosa Ribeiro CM. Modelling dysregulated $\mathrm{Na}^{+}$absorption in airway epithelial cells with mucosal nystatin treatment. Am J Respir Cell Mol Biol 2008;38:423434.

15. Mall M, Grubb BR, Harkema JR, O'Neal WK, Boucher RC. Increased airway epithelial $\mathrm{Na}^{+}$absorption produces cystic fibrosis-like lung disease in mice. Nat Med 2004;10:487-493.

16. Frizzell RA, Pilewski JM. Finally, mice with CF lung disease. Nat Med 2004;10:452-454. 
17. Mall MA, Harkema JR, Trojanek JB, Treis D, Livraghi A, Schubert S, Zhou Z, Kreda SM, Tilley SL, Hudson EJ, et al. Development of chronic bronchitis and emphysema in $\beta$-epithelial $\mathrm{Na}^{+}$channel-overexpressing mice. Am J Respir Crit Care Med 2008;177:730-742.

18. Mall MA. Role of cilia, mucus, and airway surface liquid in mucociliary dysfunction: lessons from mouse models. J Aerosol Med Pulm Drug Deliv 2008;21:13-24.

19. Kleyman TR, Cragoe EJ Jr. Amiloride and its analogs as tools in the study of ion transport. J Membr Biol 1988;105:1-21.

20. Graham A, Hasani A, Alton EW, Martin GP, Marriott C, Hodson ME, Clarke SW, Geddes DM. No added benefit from nebulized amiloride in patients with cystic fibrosis. Eur Respir J 1993;6:1243-1248.

21. Pons G, Marchand MC, d'Athis P, Sauvage E, Foucard C, ChaumetRiffaud P, Sautegeau A, Navarro J, Lenoir G. French multicenter randomized double-blind placebo-controlled trial on nebulized amiloride in cystic fibrosis patients. The Amiloride-AFLM Collaborative Study Group. Pediatr Pulmonol 2000;30:25-31.

22. Treggiari MM, Rosenfeld M, Retsch-Bogart G, Gibson R, Ramsey B. Approach to eradication of initial Pseudomonas aeruginosa infection in children with cystic fibrosis. Pediatr Pulmonol 2007;42:751-756.

23. Hoiby N, Frederiksen B, Pressler T. Eradication of early Pseudomonas aeruginosa infection. J Cyst Fibros 2005;4:49-54.

24. Zhou Z, Treis D, Schubert S, Harm M, Schatterny J, Hirtz S, Duerr J, Boucher RC, Mall MA. Preventive but not late ENaC blocker therapy reduces mortality and morbidity of cystic fibrosis-like lung disease in mice [abstract]. Pediatr Pulmonol Suppl 2007;30:294.

25. Mall MA, Treis D, Schubert S, Harm M, Schatterny J, Hirtz S, Duerr J, Boucher RC, Zhou Z. Preventive inhibition of increased airway $\mathrm{Na}^{+}$ absorption reduces morbidity and mortality of cystic fibrosis-like lung disease in mice [abstract]. Am J Respir Crit Care Med 2008;177:A456.

26. Harkema JR, Plopper CG, Hyde DM, St George JA. Regional differences in quantities of histochemically detectable mucosubstances in nasal, paranasal, and nasopharyngeal epithelium of the bonnet monkey. J Histochem Cytochem 1987;35:279-286.

27. Weibel ER. Morphometry of the human lung. Berlin: Springer Verlag; 1963.

28. Weibel ER, Hsia CC, Ochs M. How much is there really? Why stereology is essential in lung morphometry. $J$ Appl Physiol 2007;102:459-467.

29. Knowles MR, Church NL, Waltner WE, Yankaskas JR, Gilligan P, King M, Edwards LJ, Helms RW, Boucher RC. A pilot study of aerosolized amiloride for the treatment of lung disease in cystic fibrosis. N Engl J Med 1990;322:1189-1194.

30. Khan TZ, Wagener JS, Bost T, Martinez J, Accurso FJ, Riches DW. Early pulmonary inflammation in infants with cystic fibrosis. Am J Respir Crit Care Med 1995;151:1075-1082.

31. Berger M. Lung inflammation early in cystic fibrosis: bugs are indicted, but the defense is guilty. Am J Respir Crit Care Med 2002;165:857858.

32. Gibson RL, Burns JL, Ramsey BW. Pathophysiology and management of pulmonary infections in cystic fibrosis. Am J Respir Crit Care Med 2003;168:918-951.

33. Adkins B, Leclerc C, Marshall-Clarke S. Neonatal adaptive immunity comes of age. Nat Rev Immunol 2004;4:553-564.

34. George CL, White ML, Kulhankova K, Mahajan A, Thorne PS, Snyder JM, Kline JN. Early exposure to a nonhygienic environment alters pulmonary immunity and allergic responses. Am J Physiol Lung Cell Mol Physiol 2006;291:L512-L522.

35. Simel DL, Mastin JP, Pratt PC, Wisseman CL, Shelburne JD, Spock A, Ingram P. Scanning electron microscopic study of the airways in normal children and in patients with cystic fibrosis and other lung diseases. Pediatr Pathol 1984;2:47-64.

36. Chen CJ, Kono H, Golenbock D, Reed G, Akira S, Rock KL. Identification of a key pathway required for the sterile inflammatory response triggered by dying cells. Nat Med 2007;13:851-856.

37. Ramsey BW, Pepe MS, Quan JM, Otto KL, Montgomery AB, WilliamsWarren J, Vasiljev K, Borowitz D, Bowman CM, Marshall BC, et al. Intermittent administration of inhaled tobramycin in patients with cystic fibrosis. Cystic Fibrosis Inhaled Tobramycin Study Group. $N$ Engl J Med 1999;340:23-30.

38. Ranasinha C, Assoufi B, Shak S, Christiansen D, Fuchs H, Empey D, Geddes D, Hodson M. Efficacy and safety of short-term administration of aerosolised recombinant human DNase I in adults with stable stage cystic fibrosis. Lancet 1993;342:199-202.

39. Fuchs HJ, Borowitz DS, Christiansen DH, Morris EM, Nash ML, Ramsey BW, Rosenstein BJ, Smith AL, Wohl ME. Effect of aerosolized recombinant human DNase on exacerbations of respiratory symptoms and on pulmonary function in patients with cystic fibrosis. The Pulmozyme Study Group. N Engl J Med 1994;331:637-642.

40. Grubb BR, Paradiso AM, Boucher RC. Anomalies in ion transport in CF mouse tracheal epithelium. Am J Physiol 1994;267:C293-C300.

41. Grubb BR, Boucher RC. Pathophysiology of gene-targeted mouse models for cystic fibrosis. Physiol Rev 1999;79:S193-S214.

42. Pier GB, Grout M, Zaidi TS. Cystic fibrosis transmembrane conductance regulator is an epithelial cell receptor for clearance of Pseudomonas aeruginosa from the lung. Proc Natl Acad Sci USA 1997;94:1208812093.

43. Di A, Brown ME, Deriy LV, Li C, Szeto FL, Chen Y, Huang P, Tong J, Naren AP, Bindokas V, et al. CFTR regulates phagosome acidification in macrophages and alters bactericidal activity. Nat Cell Biol 2006;8:933-944.

44. Gentzsch M, Choudhury A, Chang XB, Pagano RE, Riordan JR. Misassembled mutant $\triangle$ F508 CFTR in the distal secretory pathway alters cellular lipid trafficking. J Cell Sci 2007;120:447-455.

45. Teichgraber V, Ulrich M, Endlich N, Riethmuller J, Wilker B, OliveiraMunding CC, van Heeckeren AM, Barr ML, von Kurthy G, Schmid $\mathrm{KW}$, et al. Ceramide accumulation mediates inflammation, cell death and infection susceptibility in cystic fibrosis. Nat Med 2008;14:382391.

46. Guilbault C, De Sanctis JB, Wojewodka G, Saeed Z, Lachance C, Skinner TA, Vilela RM, Kubow S, Lands LC, Hajduch M, et al. Fenretinide corrects newly found ceramide deficiency in cystic fibrosis. Am J Respir Cell Mol Biol 2008;38:47-56.

47. Pedemonte N, Lukacs GL, Du K, Caci E, Zegarra-Moran O, Galietta LJ, Verkman AS. Small-molecule correctors of defective DeltaF508CFTR cellular processing identified by high-throughput screening. J Clin Invest 2005;115:2564-2571.

48. Du M, Liu X, Welch EM, Hirawat S, Peltz SW, Bedwell DM. PTC124 is an orally bioavailable compound that promotes suppression of the human CFTR-G542X nonsense allele in a CF mouse model. Proc Natl Acad Sci USA 2008;105:2064-2069.

49. Zeitlin PL. Emerging drug treatments for cystic fibrosis. Expert Opin Emerg Drugs 2007;12:329-336.

50. Fujii T, Hayashi S, Hogg JC, Vincent R, Van Eeden SF. Particulate matter induces cytokine expression in human bronchial epithelial cells. Am J Respir Cell Mol Biol 2001;25:265-271.

51. Rolfe MW, Kunkel SL, Rowens B, Standiford TJ, Cragoe EJ Jr, Strieter RM. Suppression of human alveolar macrophage-derived cytokines by amiloride. Am J Respir Cell Mol Biol 1992;6:576-582.

52. Hirsh AJ, Zang J, Zamurs A, Fleegle J, Thelin WR, Caldwell RA, Sabater J, Abraham WM, Donowitz M, Cha B, et al. Pharmacological properties of 552-02, a novel epithelial sodium channel blocker with potential clinical efficacy for cystic fibrosis lung disease. J Pharmacol Exp Ther 2008;325:77-88.

53. Noone PG, Regnis JA, Liu X, Brouwer KL, Robinson M, Edwards L, Knowles MR. Airway deposition and clearance and systemic pharmacokinetics of amiloride following aerosolization with an ultrasonic nebulizer to normal airways. Chest 1997;112:1283-1290.

54. Hofmann T, Stutts MJ, Ziersch A, Rückes C, Weber WM, Knowles MR, Lindemann H, Boucher RC. Effects of topically delivered benzamil and amiloride on nasal potential difference in cystic fibrosis. Am J Respir Crit Care Med 1998;157:1844-1849.

55. Hirsh AJ, Sabater JR, Zamurs A, Smith R, Paradiso A, Hopkins S, Abraham WM, Boucher RC. Evaluation of second generation amiloride analogues as therapy for CF lung disease. J Pharmacol Exp Ther 2004:311:929-938.

56. Walter MJ, Morton JD, Kajiwara N, Agapov E, Holtzman MJ. Viral induction of a chronic asthma phenotype and genetic segregation from the acute response. J Clin Invest 2002;110:165-175.

57. Holtzman MJ, Tyner JW, Kim EY, Lo MS, Patel AC, Shornick LP, Agapov E, Zhang Y. Acute and chronic airway responses to viral infection: implications for asthma and chronic obstructive pulmonary disease. Proc Am Thorac Soc 2005;2:132-140.

58. Andersen DH. Cystic fibrosis of the pancreas and its relation to celiac disease. Am J Dis Child 1938;56:344-399.

59. Zuelzer WW, Newton WA. The pathogenesis of fibrocystic disease of the pancreas; a study of 36 cases with special reference to the pulmonary lesions. Pediatrics 1949;4:53-69.

60. Grosse SD, Rosenfeld M, Devine OJ, Lai HJ, Farrell PM. Potential impact of newborn screening for cystic fibrosis on child survival: a systematic review and analysis. J Pediatr 2006;149:362-366.

61. Mehta A. A global perspective on newborn screening for cystic fibrosis. Curr Opin Pulm Med 2007;13:510-514. 
62. Jones KM, Liao E, Hohneker K, Turpin S, Henry MM, Selinger K, Hsyu PH, Boucher RC, Knowles MR, Dukes GE. Pharmacokinetics of amiloride after inhalation and oral administration in adolescents and adults with cystic fibrosis. Pharmacotherapy 1997;17:263-270.

63. Henderson WR Jr, Lu J, Poole KM, Dietsch GN, Chi EY. Recombinant human platelet-activating factor-acetylhydrolase inhibits airway inflammation and hyperreactivity in mouse asthma model. J Immunol 2000;164:3360-3367.

64. Schuepp KG, Straub D, Moller A, Wildhaber JH. Deposition of aerosols in infants and children. J Aerosol Med 2004;17:153-156.

65. Schuepp KG, Jauernig J, Janssens HM, Tiddens HA, Straub DA, Stangl R, Keller M, Wildhaber JH. In vitro determination of the optimal particle size for nebulized aerosol delivery to infants. J Aerosol Med 2005;18:225-235.

66. Hirsh AJ, Molino BF, Zhang J, Astakhova N, Geiss WB, Sargent BJ, Swenson BD, Usyatinsky A, Wyle MJ, Boucher RC, et al. Design, synthesis, and structure-activity relationships of novel 2-substituted pyrazinoylguanidine epithelial sodium channel blockers: drugs for cystic fibrosis and chronic bronchitis. J Med Chem 2006;49:40984115.

67. Cantin AM, Hanrahan JW, Bilodeau G, Ellis L, Dupuis A, Liao J, Zielenski J, Durie P. Cystic fibrosis transmembrane conductance regulator function is suppressed in cigarette smokers. Am J Respir Crit Care Med 2006;173:1139-1144.

68. Goodman RM, Yergin BM, Landa JF, Golivanux MH, Sackner MA. Relationship of smoking history and pulmonary function tests to tracheal mucous velocity in nonsmokers, young smokers, ex-smokers, and patients with chronic bronchitis. Am Rev Respir Dis 1978;117: 205-214.

69. Wanner A, Salathe M, O'Riordan TG. Mucociliary clearance in the airways. Am J Respir Crit Care Med 1996;154:1868-1902. 